\title{
Article \\ Health and Budget Impact of Liquid-Biopsy-Based Comprehensive Genomic Profile (CGP) Testing in Tissue-Limited Advanced Non-Small Cell Lung Cancer (aNSCLC) Patients
}

\author{
Yuti P. Patel ${ }^{1, *}$, Donald Husereau ${ }^{2} \mathbb{D}$, Natasha B. Leighl ${ }^{3}$, Barbara Melosky ${ }^{4} \mathbb{D}$ and Julian Nam ${ }^{5}$ \\ 1 Hoffmann-La Roche Ltd., Mississauga, ON L5N 5M8, Canada \\ 2 School of Epidemiology, Public Health and Preventive Medicine, University of Ottawa, \\ Ottawa, ON K1G 5Z3, Canada; don.husereau@gmail.com \\ 3 Princess Margaret Cancer Centre, Toronto, ON M5G 2C1, Canada; Natasha.Leighl@uhn.ca \\ 4 British Columbia Cancer Agency, Vancouver, BC V5Z 4E6, Canada; BMelosky@bccancer.bc.ca \\ 5 Hoffmann-La Roche Ltd., Grenzacherstrasse 124, Bldg 1/Floor 12, CH-4070 Basel, Switzerland; \\ julian.nam@roche.com \\ * Correspondence: yuti.patel@mail.utoronto.ca
}

Citation: Patel, Y.P.; Husereau, D.; Leighl, N.B.; Melosky, B.; Nam, J. Health and Budget Impact of Liquid-Biopsy-Based Comprehensive Genomic Profile (CGP) Testing in Tissue-Limited Advanced Non-Small Cell Lung Cancer (aNSCLC) Patients. Curr. Oncol. 2021, 28, 5278-5294. https://doi.org/10.3390/ curroncol28060441

Received: 18 November 2021 Accepted: 7 December 2021 Published: 11 December 2021

Publisher's Note: MDPI stays neutral with regard to jurisdictional claims in published maps and institutional affiliations.

Copyright: (c) 2021 by the authors. Licensee MDPI, Basel, Switzerland. This article is an open access article distributed under the terms and conditions of the Creative Commons Attribution (CC BY) license (https:// creativecommons.org/licenses/by/ $4.0 /)$.

\begin{abstract}
BACKGROUND AND OBJECTIVES: Molecular genetic testing using tissue biopsies can be challenging for patients due to unfavorable tumor sites, the invasive nature of a tissue biopsy, and the added time of booking a repeat biopsy (re-biopsy). Centers in Canada have found insufficient tissue rates to be approximately $10 \%$, and even among successful biopsies, insufficient DNA in tissue samples is approximately $16 \%$, triggering the lengthy process of re-biopsies. Using aNSCLC as an example, this study sought to characterize the health and budget impact of alternative liquidbiopsy(LBx)-based comprehensive genomic profile (CGP) testing in tissue-limited patients (TLLBx-CGP) from a Canadian publicly funded healthcare perspective. MATERIAL AND METHODS: An economic model was developed to estimate the incremental cost and life-years gained as a population associated with adopting TL-LBx-CGP. The eligible patient population was modeled using a top-down epidemiological approach based on the published literature and expert clinician input. Treatment allocation was modeled based on biomarker prevalence in the published literature, and the availability of funded therapies. Costs included molecular testing, as well as drug, administrative, and supportive costs, and relevant health data included median overall survival and median progressionfree survival data. RESULTS: Incorporation of TL-LBx-CGP demonstrated an overall impact of \$14.7 million with 168 life-years gained to the Canadian publicly funded healthcare system in the 3-year time horizon.
\end{abstract}

Keywords: liquid biopsy; comprehensive genomic profiling; tissue-limited; health and budget impact; non-small cell lung cancer; next generation sequencing; single-gene testing; Canadian public payers

\section{Introduction}

Cancer diagnosis and treatment are rapidly evolving, driven by enhanced understanding of cancer at the molecular level [1]. Over the past decade, personalized, targeted treatments based on the genomic features of a patient's cancer are associated with improved response rates, progression-free survival (PFS), and overall survival (OS) compared to non-targeted, systemic treatments [2-6]. This is especially true for lung cancer, and in particular, for non-small cell lung cancer (NSCLC), which accounts for $85 \%$ of all lung cancers, with $63 \%$ of cases detected in advanced stages (aNSCLC) [7]. Given that NSCLC is complex and driven by a broad range of potentially targetable genetic alterations, deploying a robust approach to molecular genetic testing is increasingly essential to support informed decisions on optimal therapies for individual patients. 
Currently, in Canada, actionable mutations which guide treatment selection for hlNSCLC are limited to anaplastic lymphoma kinase 1 (ALK1), epidermal growth factor receptor (EGFR), roto-oncogene tyrosine-protein kinase 1 (ROS1), and B-Raf proto-oncogene (BRAF) [8-11]. However, genetic testing for these alterations is typically performed through single-gene and hotspot multi-gene testing methods which are unable to detect copy number variations or rearrangements which can aid in clinical interpretation [12]. Furthermore, tissue exhaustion can limit the number of single tests that can be performed [12]. These challenges may be mitigated with the use of comprehensive genetic profiling (CGP) using massive parallel, or next-generation sequencing (NGS) technologies to more broadly test for genomic alterations with a single test. NGS allows for the identification of low frequency mutations missed through conventional panels, more precise diagnosis and prognosis prediction, the selection of patients for optimal targeted therapies, and the ability to identify resistance mutations to guide subsequent lines of therapy [13]. The extensive capabilities of NGS now offer oncologists the option to deliver a higher level of personalized care to cancer patients that optimizes treatment choices and results in improved outcomes [13]. In the therapeutic area of hematological cancer, studies have demonstrated the application of liquid-biopsy-based biomarkers for the diagnosis of solid and liquid cancers [14].

Testing is often complicated for aNSCLC patients due to issues including unfavorable tumor site, clinical frailty of lung tissue, lack of tissue obtained after a biopsy, the invasive nature of a tissue biopsy, and the time and availability of resources for performing a biopsy [15]. Centers in Canada have found insufficient tissue rates to be approximately $10 \%$, and even among successful biopsies, insufficient DNA in tissue samples occurs in $16 \%$ of tests, triggering a lengthy process of repeat biopsies (re-biopsies) [16]. Moreover, of patients with adequate tissue for molecular genetic testing, $75 \%$ are tested using a single gene methodology, but approximately $29 \%$ cannot continue with additional genetic testing due to tissue exhaustion $[17,18]$. In cases in which appropriate testing is not employed, targeted treatment is unavailable to a number of NSCLC patients, and the ability to identify patients for some clinical trials is limited. This restricts physicians to systemic chemotherapies which could result in worse clinical outcomes than if they could match to an appropriate, targeted therapy. This highlights a gap in the treatment journey amongst "tissue-limited" (TL) aNSCLC patients, defined as individuals who encounter the following: insufficient tissue for molecular genetic testing; insufficient DNA in tissue samples requiring re-biopsies; or exhausted tissue from single-gene testing.

Circulating tumor DNA (ctDNA), commonly referred to as liquid biopsy (LBx), presents a case for alternative molecular genetic profiling in these tissue-limited (i.e., TL-LBx) scenarios. Clinical validation studies have demonstrated that LBx-based NGS shows a high positive concordance to tissue-based NGS [19]. An example of LBx-based CGP testing is FoundationOne Liquid ${ }^{\circledR}$ CDx, launched in June 2020. Using a blood sample, FoundationOne Liquid ${ }^{\circledR}$ analyzes and detects novel and known variants of the four main classes of genomic alterations in more than 300 genes and genomic signatures, such as blood tumor mutational burden (bTMB), and microsatellite instability (MSI) status, to help inform treatment decisions and identify potential clinical trials for patients with advanced cancer [20]. However, despite the availability of advanced testing technologies, the utilization of LBx-CGP remains low.

Though there appears to be a clear benefit to using a TL-LBx-CGP approach, policymakers still need to understand the impact on patients and healthcare expenditures to facilitate its widespread adoption. To address this, and using aNSCLC as an example, this study sought to characterize the health and budget impact of alternative TL-LBx-CGP testing in tissue-limited patients from a Canadian publicly funded healthcare perspective.

\section{Materials and Methods}

\subsection{Model Structure}

The health and budget impact of adopting alternative TL-LBx-CGP in aNSCLC patients was assessed from a Canadian publicly funded healthcare perspective over a three- 
year time horizon. An economic model was developed in a Microsoft Excel spreadsheet which estimated the number of patients who could receive targeted therapies rather than non-targeted therapies due to identification of an actionable mutation, and then estimated the incremental population life-years (LYs), and costs associated with funding TL-LBx-CGP (refer to Figure 1). The eligible patient population was modelled using a reference (TL-LBxCGP, not publicly funded) and new (TL-LBx-CGP, publicly funded) scenario through a two-step process: market size estimation and treatment distribution.

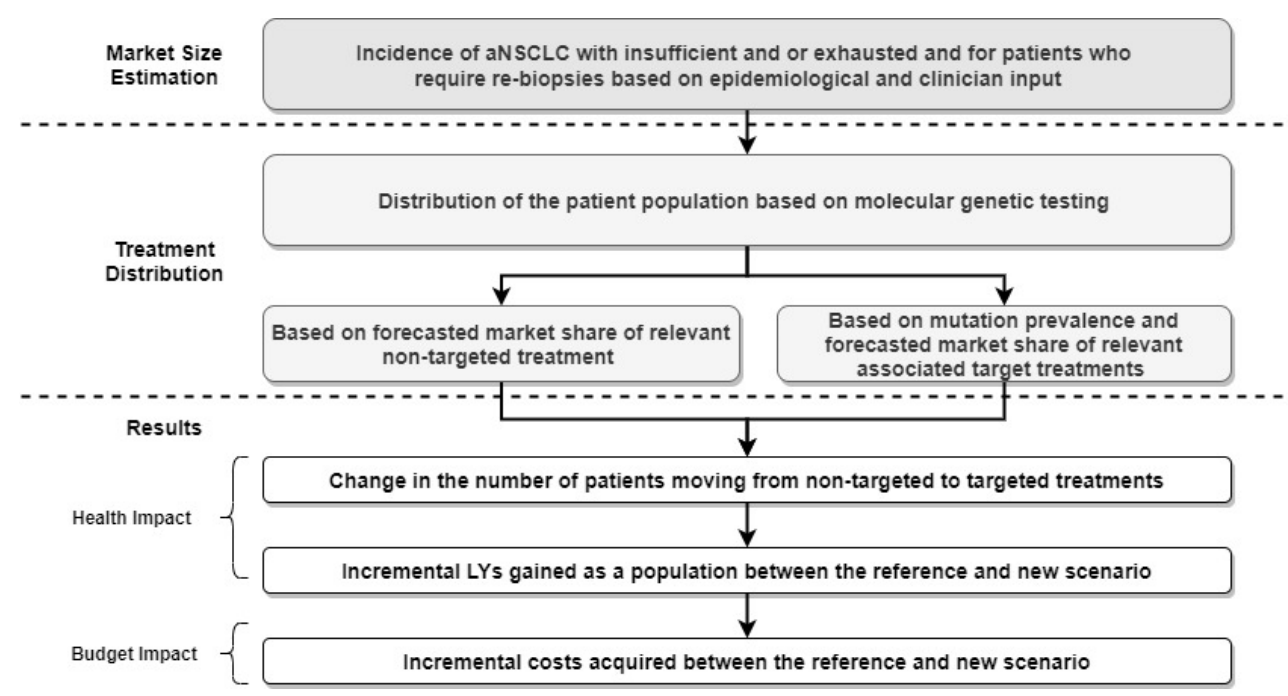

Figure 1. Health and budget impact model overview.

\subsubsection{Market Size Estimation}

To estimate market size, a top-down epidemiological approach based on the published literature and expert clinician input was used (Figure 2). Canadian incident lung cancer was used as a starting point, and subsequent epidemiological filters were applied until the biomarker testing point in the patient journey. Of the patients who receive treatment, $28 \%$ of aNSCLC patients don't receive biomarker testing, in which $10 \%$ are due to insufficient tissue [13]. Of the $72 \%$ that receive biomarker testing, $16 \%$ require re-biopsies due to inadequate DNA in the tissue sample [13]. For those patients with adequate tissue samples, $25 \%$ receive multigene assay panel testing, whereas $75 \%$ have single-gene testing, as depicted in Figure 2 and Tables 1 and 2 [15-17]. As depicted in Table 2, the adoption of TL-LBx-CGP leads to all patients having access to molecular genetic testing (versus the reference scenario) through either: NGS; single-gene testing; or TL-LBx-CGP; and no patients in the "no testing" category.

Table 1. (a) Market size estimation—reference scenario. (b) Market size estimation—new scenario.

\begin{tabular}{ccccc}
\hline (a) Market Size Estimation-Reference Scenario & & \\
\hline Patient Flow & $\mathbf{2 0 2 0}$ & $\mathbf{2 0 2 1}$ & $\mathbf{2 0 2 2}$ & $\mathbf{2 0 2 3}$ \\
\hline Lung cancer patients & 23,093 & 23,593 & 24,104 & 24,626 \\
\hline NSCLC patients & 19,629 & 20,054 & 20,488 & 20,932 \\
\hline Locally advanced/metastatic & 12,366 & 12,634 & 12,908 & 13,187 \\
\hline Non-squamous NSCLC & 8657 & 8844 & 9035 & 9231 \\
\hline Patients who receive treatment & 2597 & 2653 & 2711 & 2769 \\
\hline Biomarker testing not performed & 727 & 743 & 759 & 76 \\
\hline Patients with insufficient tissue for biomarker testing * & 73 & 74 & 78 \\
\hline Biomarker testing performed & 1870 & 1910 & 1952
\end{tabular}


Table 1. Cont.

\begin{tabular}{|c|c|c|c|c|}
\hline \multicolumn{5}{|c|}{ (a) Market Size Estimation-Reference Scenario } \\
\hline Patient Flow & 2020 & 2021 & 2022 & 2023 \\
\hline Inadequate tissue for conventional testing & 299 & 306 & 312 & 319 \\
\hline Re-biopsy performed & 239 & 245 & 250 & 255 \\
\hline Re-biopsy not performed * & 60 & 61 & 62 & 64 \\
\hline Adequate tissue for testing & 1810 & 1849 & 1889 & 1930 \\
\hline Broad-based NGS testing performed * & 452 & 462 & 472 & 483 \\
\hline Sequential single-gene testing performed * & 1357 & 1387 & 1417 & 1448 \\
\hline Patient able to continue sequential testing & 964 & 985 & 1006 & 1028 \\
\hline Patients unable to continue due to tissue exhaustion * & 394 & 402 & 411 & 420 \\
\hline Total number of patients & 1943 & 1985 & 2028 & 2071 \\
\hline \multicolumn{5}{|c|}{ (b) Market Size Estimation-New Scenario } \\
\hline Patient Flow & 2020 & 2021 & 2022 & 2023 \\
\hline Lung cancer patients & 23,093 & 23,593 & 24,104 & 24,626 \\
\hline NSCLC patients & 19,629 & 20,054 & 20,488 & 20,932 \\
\hline Locally advanced/metastatic & 12,366 & 12,634 & 12,908 & 13,187 \\
\hline Non-squamous NSCLC & 8657 & 8844 & 9035 & 9231 \\
\hline Patients who receive treatment & 2597 & 2653 & 2711 & 2769 \\
\hline Biomarker testing not performed & 727 & 743 & 759 & 775 \\
\hline TL-LBx-CGP Eligible: & 73 & 74 & 76 & 78 \\
\hline \multicolumn{5}{|l|}{ Patients with insufficient tissue for biomarker testing * } \\
\hline Biomarker testing performed & 1870 & 1910 & 1952 & 1994 \\
\hline $\begin{array}{l}\text { TL-LBx-CGP Eligible: } \\
\text { Inadequate tissue for conventional testing }\end{array}$ & 299 & 306 & 312 & 319 \\
\hline Re-biopsy performed & 239 & 0 & 0 & 0 \\
\hline Re-biopsy not performed * & 60 & 0 & 0 & 0 \\
\hline Adequate tissue for testing & 1810 & 1605 & 1639 & 1675 \\
\hline Broad-based NGS testing performed * & 452 & 401 & 410 & 419 \\
\hline Sequential single-gene testing performed ${ }^{*}$ & 1357 & 1203 & 1230 & 1256 \\
\hline Patient able to continue sequential testing & 964 & 854 & 873 & 892 \\
\hline $\begin{array}{l}\text { TL-LBx-CGP Eligible: } \\
\text { Patients unable to continue due to tissue exhaustion * }\end{array}$ & 394 & 349 & 357 & 364 \\
\hline Total number of patients & 1943 & 1985 & 2028 & 2071 \\
\hline
\end{tabular}

* These numbers were summed to determine the total number of patients (market size). Values in the table above are subject to rounding.

Table 2. (a) Molecular genetic testing distribution—reference scenario. (b) Molecular genetic testing distribution-new scenario.

\begin{tabular}{ccccc}
\hline \multicolumn{2}{c}{ (a) Molecular Genetic Testing Distribution-Reference Scenario } & \\
\hline Molecular Genetic Test & $\mathbf{2 0 2 0}$ & $\mathbf{2 0 2 1}$ & $\mathbf{2 0 2 2}$ & $\mathbf{2 0 2 3}$ \\
\hline Eligible Patients & $\mathbf{1 9 4 3}$ & $\mathbf{1 9 8 5}$ & $\mathbf{2 0 2 8}$ & $\mathbf{2 0 7 1}$ \\
\hline NGS & & & & \\
\hline NGS Only & 393 & 401 & 410 & 419 \\
\hline NGS + Re-biopsy & 60 & 61 & 62 & 64 \\
\hline Single-gene testing & & & & \\
\hline Single-gene testing only & 836 & 854 & 873 & 892 \\
\hline single-gene testing + Re-biopsy & 127 & 130 & 133 & 136 \\
\hline
\end{tabular}


Table 2. Cont.

\begin{tabular}{ccccc}
\hline \multicolumn{5}{c}{ (a) Molecular Genetic Testing Distribution-Reference Scenario } \\
\hline Molecular Genetic Test & $\mathbf{2 0 2 0}$ & $\mathbf{2 0 2 1}$ & $\mathbf{2 0 2 2}$ & $\mathbf{2 0 2 3}$ \\
\hline Eligible Patients & $\mathbf{1 9 4 3}$ & $\mathbf{1 9 8 5}$ & $\mathbf{2 0 2 8}$ & $\mathbf{2 0 7 1}$ \\
\hline No testing & 526 & 538 & 549 & 561 \\
\hline TL-LBx-CGP & 0 & 0 & 0 & 0 \\
\hline (b) Molecular Genetic Testing Distribution-New Scenario & \\
\hline Molecular Genetic Test & $\mathbf{2 0 2 0}$ & $\mathbf{2 0 2 1}$ & $\mathbf{2 0 2 2}$ & $\mathbf{2 0 2 3}$ \\
\hline Eligible Patients & $\mathbf{1 9 4 3}$ & $\mathbf{1 9 8 5}$ & $\mathbf{2 0 2 8}$ & $\mathbf{2 0 7 1}$ \\
\hline NGS & & & & \\
\hline NGS Only & 393 & 401 & 410 & 419 \\
\hline NGS + Re-biopsy & 60 & 0 & 0 & 0 \\
\hline Single-gene testing & & & 873 \\
\hline Single-gene testing only & 836 & 854 & 0 & 0 \\
\hline single-gene testing + Re-biopsy & 127 & 0 & 0 & 0 \\
\hline No testing & 526 & 0 & 745 & 761 \\
\hline TL-LBx-CGP & 0 & 729 &
\end{tabular}

Values in the table above are subject to rounding.

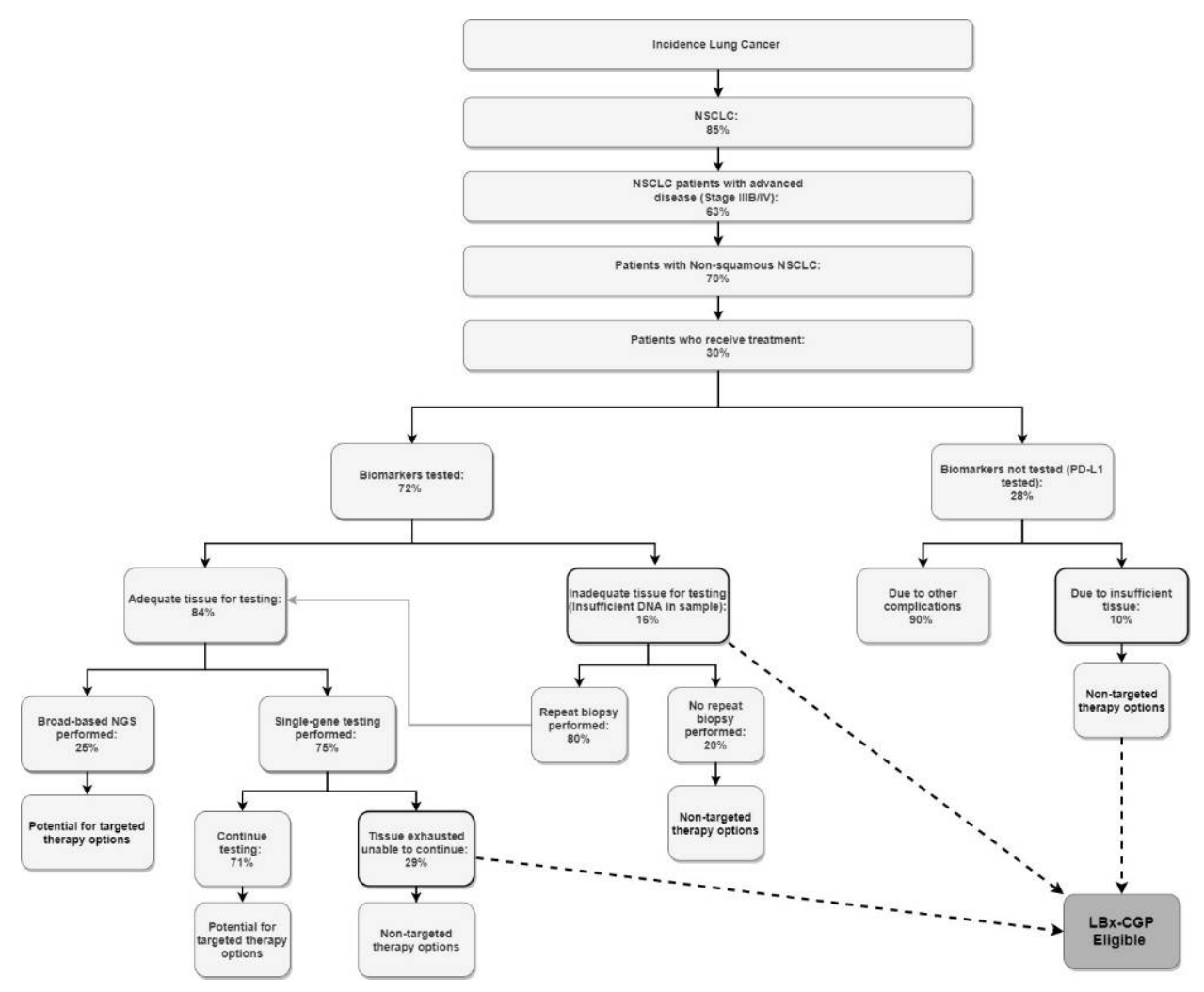

Figure 2. Market size estimation: patient testing journey.

\subsubsection{Treatment Distribution}

Eligible patients in each scenario receive publicly-funded first-line treatment options based on the likelihood of receiving molecular genetic testing results, and biomarker prevalence rates (Table 3). It was assumed that PD-L1 was tested for all patients. Biomarkers tested in the new scenario are based on the NCCN guidelines for mutations recommended 
for testing (EGFR, ALK, ROS1, BRAF V600E), as well as the NTRK mutation; however, currently in Canada, there no funded therapies for BRAF or NTRK positive, and thus, those patients were placed in the "no match" arm. The model assumed patients who received molecular genetic testing are eligible for targeted therapies (Figure 3), and patients who received no molecular genetic testing are eligible for non-targeted therapies (Figure 4). Upon progression from first-line treatment, patients are distributed appropriately into approved, publicly funded second-line treatments.

Table 3. (a) Treatment distribution—reference scenario. (b) Treatment distribution—new scenario.

\begin{tabular}{|c|c|c|c|c|}
\hline \multicolumn{5}{|c|}{ (a) Treatment Distribution-Reference Scenario } \\
\hline 2020 & 2020 & 2021 & 2022 & 2023 \\
\hline Eligible Patients & 1943 & 1985 & 2028 & 2071 \\
\hline \multicolumn{5}{|l|}{ First-line Therapy } \\
\hline Osimertinib & 241 & 246 & 251 & 257 \\
\hline Alectinib & 42 & 43 & 44 & 45 \\
\hline Crizotinib & 7 & 7 & 7 & 8 \\
\hline Entrectinib & 7 & 7 & 7 & 8 \\
\hline Carboplatin Pemetrexed & 329 & 336 & 343 & 351 \\
\hline Carboplatin + Pemetrexed + Pembrolizumab & 823 & 840 & 859 & 877 \\
\hline Pembrolizumab & 494 & 504 & 515 & 526 \\
\hline \multicolumn{5}{|l|}{ Second-Line Therapy } \\
\hline Carboplatin + Pemetrexed & 430 & 439 & 449 & 458 \\
\hline Docetaxel & 494 & 673 & 687 & 702 \\
\hline Nivolumab & 168 & 229 & 234 & 239 \\
\hline Pembrolizumab & 84 & 114 & 117 & 119 \\
\hline Atezolizumab & 28 & 38 & 39 & 40 \\
\hline Total number of patients progressed to $2 \mathrm{~L}$ & 1203 & 1493 & 1526 & 1559 \\
\hline \multicolumn{5}{|c|}{ (b) Treatment Distribution-New Scenario } \\
\hline Treatment & 2020 & 2021 & 2022 & 2023 \\
\hline Eligible Patients & 1943 & 1985 & 2028 & 2071 \\
\hline \multicolumn{5}{|l|}{ First-line Therapy } \\
\hline Osimertinib & 241 & 337 & 345 & 352 \\
\hline Alectinib & 42 & 60 & 61 & 62 \\
\hline Crizotinib & 7 & 10 & 10 & 10 \\
\hline Entrectinib & 7 & 10 & 10 & 10 \\
\hline Carboplatin Pemetrexed & 329 & 314 & 320 & 327 \\
\hline Carboplatin + Pemetrexed + Pembrolizumab & 823 & 784 & 801 & 818 \\
\hline Pembrolizumab & 494 & 470 & 481 & 491 \\
\hline \multicolumn{5}{|l|}{ Second-Line Therapy } \\
\hline Carboplatin + Pemetrexed & 430 & 470 & 480 & 490 \\
\hline Docetaxel & 494 & 470 & 481 & 491 \\
\hline Nivolumab & 168 & 160 & 163 & 167 \\
\hline Pembrolizumab & 84 & 80 & 82 & 83 \\
\hline Atezolizumab & 28 & 27 & 27 & 28 \\
\hline Total number of patients progressed to $2 \mathrm{~L}$ & 1203 & 1207 & 1233 & 1259 \\
\hline
\end{tabular}




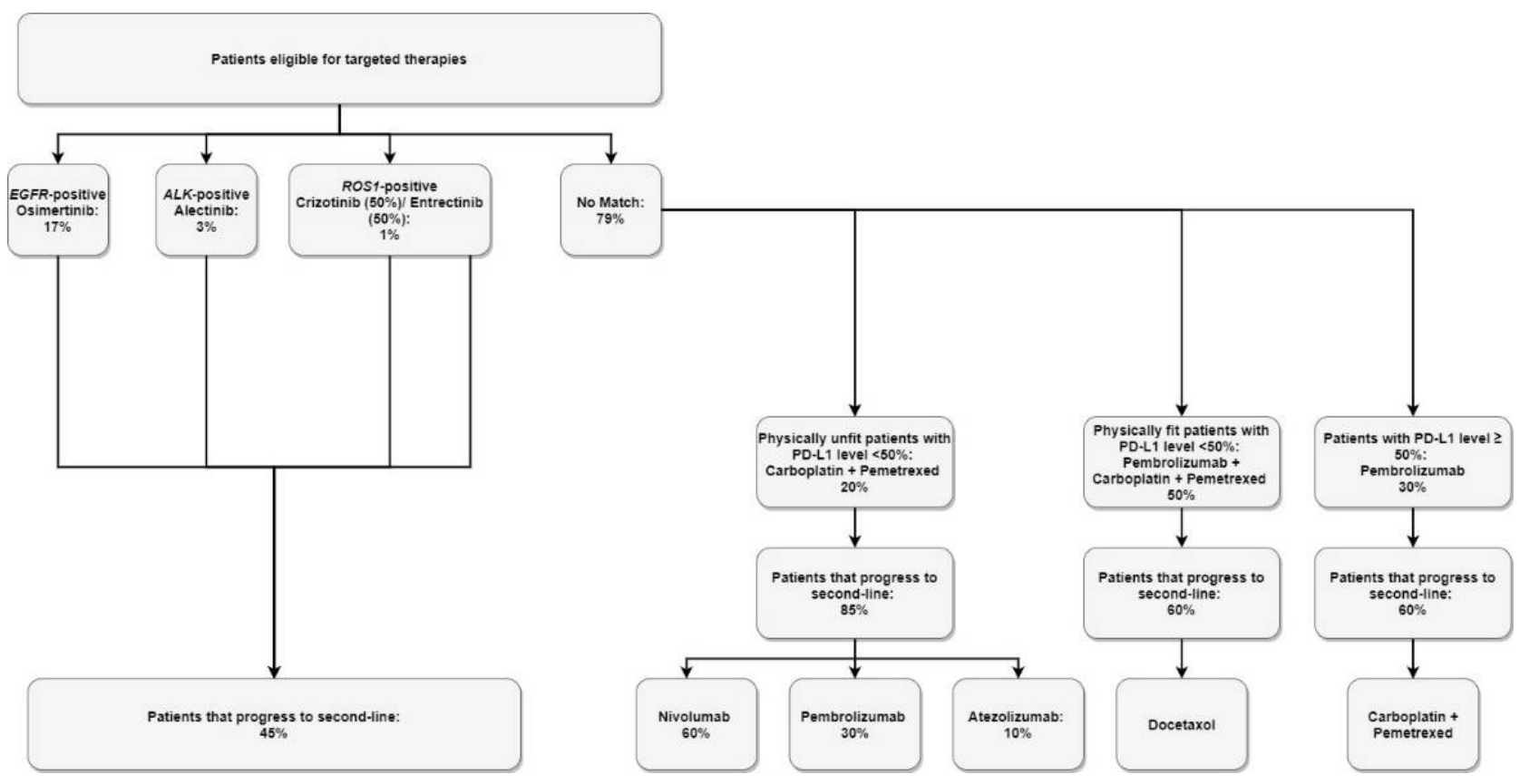

Figure 3. Treatment distribution: targeted therapies.

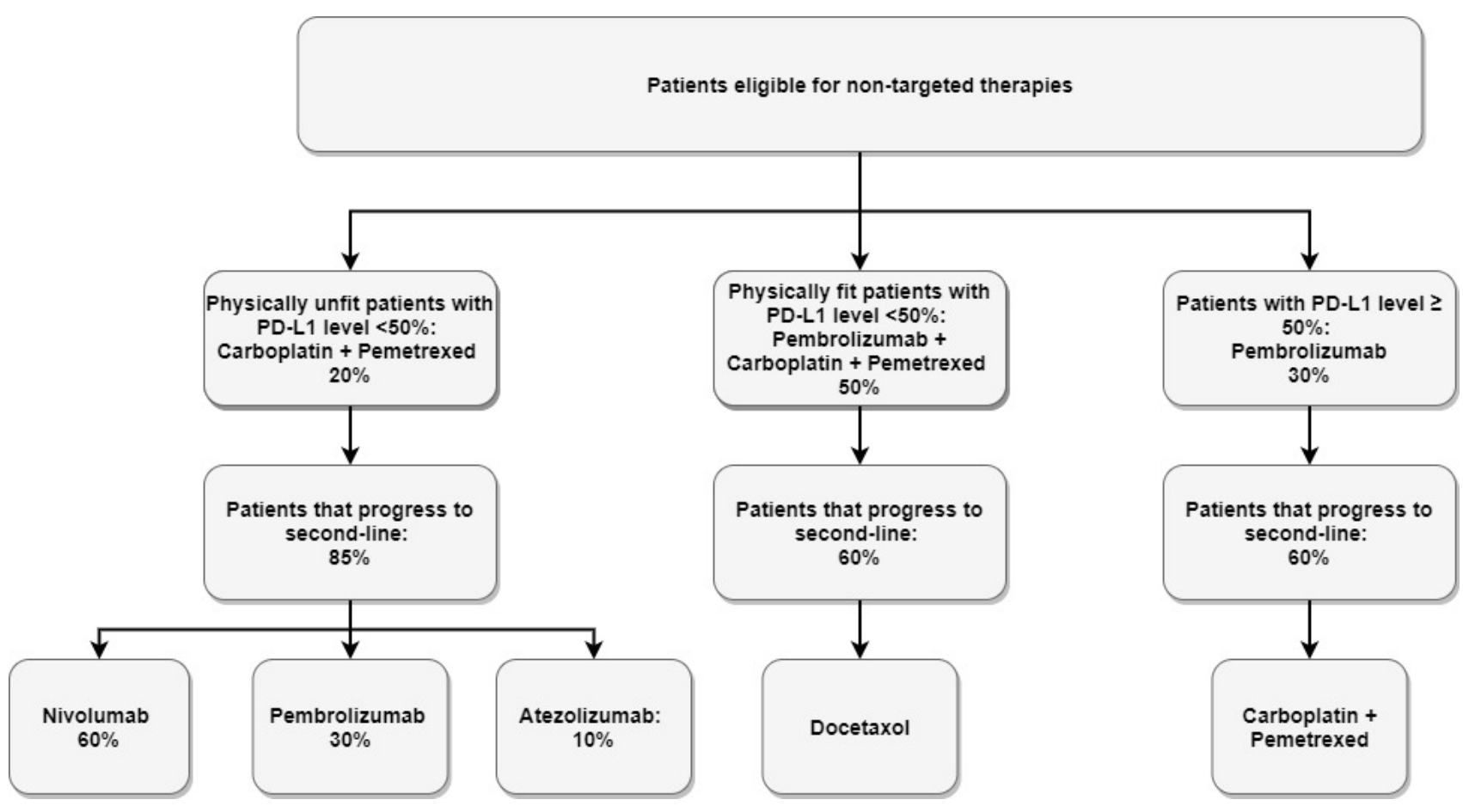

Figure 4. Treatment distribution: non-targeted therapies.

\subsection{Health Impact Analysis}

The base case for the health impact was informed by the change in the number of patients moving from non-targeted to targeted therapies, and the associated incremental LYs gained for annual population cohorts over a 3-year time horizon. Change in the number of patients moving from non-targeted therapies to targeted was estimated by monitoring the incident patients distributed into the different types of therapies (chemotherapy, immunotherapy, chemo-immunotherapy, and targeted therapy) per Year in the reference versus new scenario. The population LYs in each scenario were calculated by multiplying 
the number of patients distributed to the respective treatments by the median overall survival (mOS) (Table 4). Carry-over beyond one year was assigned to cohorts receiving treatments with mOS values greater than 12 months. As an exploratory result, the lifetime LYs gained as a population were calculated by carrying-forward all incident patients captured within the 3-year time horizon until the end of their mOS. A sample calculation for incremental population LYs using osimertinib is presented in Figure 5.

Table 4. Health outcomes data.

\begin{tabular}{ccccc}
\hline Treatment & Mutation & $\begin{array}{c}\text { mOS } \\
\text { (Months) }\end{array}$ & $\begin{array}{c}\text { mPFS } \\
\text { (Months) }\end{array}$ & Source \\
\hline Osimertinib & EGFR & 38.6 & 18.9 & [21] \\
\hline Alectinib & ALK & 58.4 & 34.8 & [22] \\
\hline Crizotinib & ROS1 & 51.4 & 19.3 & [23] \\
\hline Entrectinib & ROS1 & 62.3 & 15.7 & [24] \\
\hline Carboplatin + Pemetrexed (1L/2L) & $\begin{array}{c}\text { Unknown } \\
\text { levels of } \\
\text { PD-L1 }\end{array}$ & 10.7 & 4.9 & [25] \\
\hline Pembrolizumab + Carboplatin + & $\begin{array}{c}\text { Negative/low } \\
\text { levels } \\
\text { Pemetrexed }\end{array}$ & 22 & 9.0 & [25] \\
\hline PD-L1 & High levels & 30 & 10.3 & [26] \\
\hline of PD-L1 & N/A & 4.2 & 2.0 & [27] \\
\hline Docetaxel & N/A & 12.2 & 2.3 & [28] \\
\hline Nivolumab & N/A & 10.5 & 3.8 & [29] \\
\hline Atezolizumab & N/A & 13.8 & 2.8 & [30] \\
\hline
\end{tabular}

1L: First-line treatment; 2L: Second-line treatment.

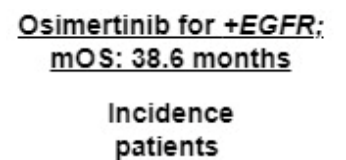

Base year: 2020

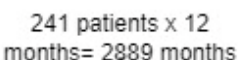

2021

2022

2023

patients 246 patients $\times 12$
months $=2952$ months months $=2952$ months
251 patients $\times 12$ months $=3016$ months months $=3081$ months

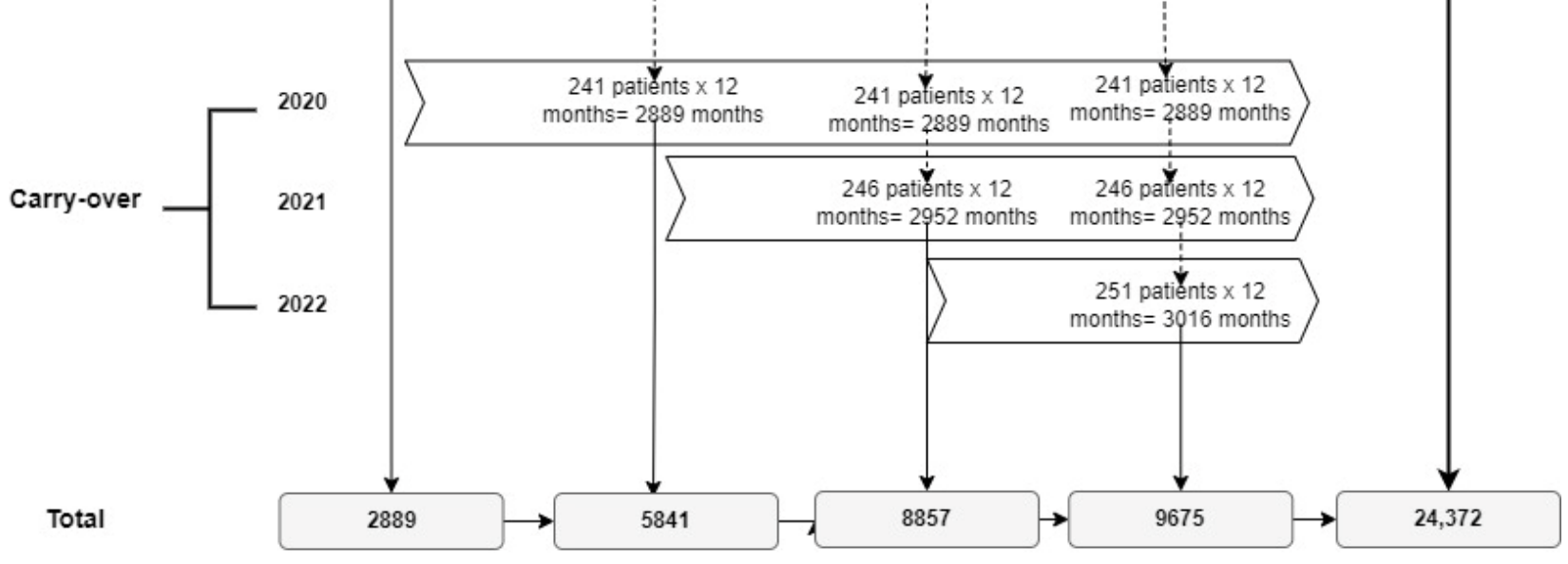

Figure 5. Health impact sample calculation. 


\subsection{Budget Impact Analysis}

\subsubsection{Cost Inputs}

There were four cost categories included for molecular testing costs: NGS; single-gene testing; TL-LBx-CGP; and re-biopsies. Table 5 presents the cost per patient for each of the testing methodologies considered. To be conservative, the list price of FoundationOne Liquid $C D x^{\circledR}$ was utilized as a proxy for a commercial TL-LBx-based CGP test. An assumption in this analysis is that two negative single gene tests completed prior to tissue exhaustion is equivalent to twice the list price (\$652) [8]. The cost of NGS, single gene, and re-biopsies includes all direct hospital costs and professional fees.

Table 5. Annual molecular genetic testing costs (per patient).

\begin{tabular}{cl}
\hline Cost Categories & Cost per Year \\
\hline NGS & $\$ 1919.00[12]$ \\
Single- gene testing (two tests) & $\$ 1304.00[12]$ \\
TL-LBx CGP & $\$ 6193.60[12]$ \\
Re-biopsies & $\$ 1948.26[31]$ \\
\hline
\end{tabular}

Drug costs included in each line of therapy were based on list-price of approved and publicly funded interventions. The total cost per treatment was determined by the Health-Canada-recommended dosage and unit cost (details outlined in the Supplementary Materials) [32]. The overall annual drug cost per patient was calculated according to the number of treatment cycles in a year, using median progression free survival (mPFS) data as a proxy for average treatment length (Table 4).

Administrative costs included chair time [33,34], pharmacists [34], clinician consultation [35], and pre-medication cost [32] (details outlined in Supplementary Materials). For oral treatments, the total annual costs per patient were calculated on a weekly basis, and for IV treatments, the costs calculated per every 21 days (typically the length of one cycle). Supportive costs included clinician consultation [35], laboratory testing [36], and imaging procedure costs $[31,35]$ (details outlined in Supplementary Materials). Similar to administrative costs, total annual oral treatments supportive costs per patient were calculated on a weekly basis, and for IV treatments, the costs are per every 21 days.

The total annual costs (aggregated and disaggregated) per patient per therapy are presented in Appendix A.

\subsubsection{Analysis and Assumptions}

The net annual impact was estimated by determining the number of patients distributed to each of the different treatments, and calculating the treatment duration, in cycles. Median-progression-free (mPFS) survival data (Table 4) associated with each treatment was used as a proxy for treatment duration. Carryover costs for treatments with mPFS $>12$ months were handled similarly to LYs calculations with mOS $>12$ months. The total cost per treatment in each scenario was determined by multiplying the total number of cycles in a year by each of the cost categories. Further, total costs per treatment were multiplied by total number of patients distributed to the treatment, and summed in each scenario to calculate the annual incremental difference (new scenario less reference scenario) starting with the base year, 2020, followed by a 3-year time horizon.

\subsection{Sensitivity and Scenario Analysis}

Uncertainty was explored through one-way sensitivity analyses (Table 6). The Canadian publicly funded healthcare system is composed of federated healthcare structures, is siloed, and cost categories are accounted for in various budgets. As such, a scenario from a Canadian testing budget perspective was performed, in which only molecular genetic testing costs were considered. 
Table 6. Health outcomes data.

\begin{tabular}{ccc}
\hline Parameter & Base Case & Sensitivity Analysis \\
\hline Epidemiological Inputs & & \\
\hline Lung cancer patients with NSCLC & $85 \%$ & $\pm 10 \%$ \\
NSCLC patients with advanced disease (Stage 3B/4A) & $63 \%$ & $\pm 10 \%$ \\
\hline Patients with non-squamous NSCLC & $70 \%$ & $\pm 10 \%$ \\
Patients who receive treatment & $30 \%$ & $\pm 10 \%$ \\
\hline Molecular genetic testing inputs & & \\
Biomarker not tested, excluding PD-L1 & $28 \%$ & $\pm 10 \%$ \\
Patients with insufficient tissue for biomarker testing & $10 \%$ & $\pm 5 \%$ \\
Adequate tissue for testing & $84 \%$ & $\pm 10 \%$ \\
Re-biopsy performed & $80 \%$ & $\pm 25 \%$ \\
Broad-based NGS testing performed & $25 \%$ & $-50 \%$ \\
( & $+75 \%$ \\
Patients unable to continue due to tissue exhaustion & $29 \%$ & $\pm 10 \%$ \\
\hline Molecular genetic testing cost inputs & & \\
TL-LBx-CGP (FoundationOne Liquid CDx ${ }^{\circledR}$ ) & $\$ 6193.60$ & Discount: $25 \%, 50 \%, 75 \%$ \\
Single-gene testing & $\$ 1304.00$ & Discount: $25 \%, 50 \%, 75 \%$ \\
Re-biopsy & $\$ 1948.26$ & Discount: $25 \%, 50 \%, 75 \%$ \\
Broad-based NGS & $\$ 1919.00$ & Discount: $25 \%, 50 \%, 75 \%$ \\
\hline
\end{tabular}

\section{Results}

\subsection{Health Impact}

Public funding of TL-LBx-CGP resulted in an estimated 346 more patients accessing targeted therapies over the 3-year time horizon as opposed to chemotherapies (78 fewer patients), immunotherapies (117 fewer patients), and chemo-immunotherapies (195 fewer patients) (Figure 6). Because of access to targeted therapies, the entire tissue-limited population gained $2 \mathrm{LYs}$ in year 1, 34 LYs in year 2, $131 \mathrm{LYs}$ in year 3, and a combined total of 168 LYs in the first 3 years (Tables 7-9). Five-hundred and seventy-four LYs were also accrued beyond the 3-year timeframe; however, additional downstream costs were not estimated for this period.

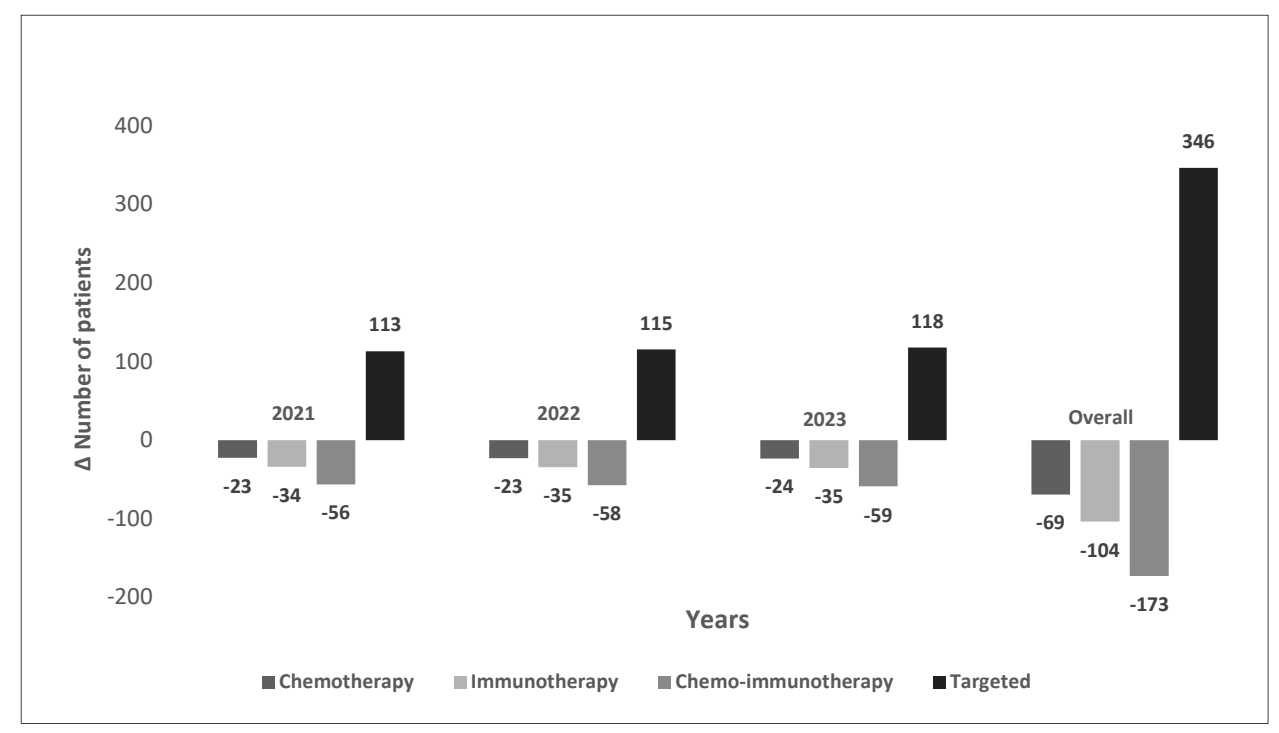

Figure 6. Change in the number of patients moving from non-targeted to targeted therapies. 
Table 7. Population LYs gained-reference scenario.

\begin{tabular}{ccccccc}
\hline Treatment & $\mathbf{2 0 2 0}$ & $\mathbf{2 0 2 1}$ & $\mathbf{2 0 2 2}$ & $\mathbf{2 0 2 3}$ & $\begin{array}{c}\text { 3-Year } \\
\text { Combined }\end{array}$ & Life-Time \\
\hline Osimertinib & 2889 & 5841 & 8857 & 9675 & 24,372 & 35,511 \\
\hline Alectinib & 510 & 1031 & 1563 & 2107 & 4700 & 9743 \\
\hline Crizotinib & 85 & 172 & 260 & 351 & 783 & 1419 \\
\hline Entrectinib & 85 & 172 & 260 & 351 & 783 & 1738 \\
\hline $\begin{array}{c}\text { Carboplatin }+ \\
\text { Pemetrexed }\end{array}$ & 3521 & 3597 & 3675 & 3754 & 11,025 & 11,025 \\
\hline $\begin{array}{c}\text { Carboplatin }+ \\
\text { Pemetrexed }+\end{array}$ & 9871 & 18,310 & 18,706 & 19,111 & 56,127 & 64,898 \\
Pembrolizumab & 5922 & 11,973 & 15,193 & 15,522 & 42,688 & 55,252 \\
\hline Pembrolizumab & $\mathbf{2 2 , 8 8 3}$ & $\mathbf{4 1 , 0 9 5}$ & $\mathbf{4 8 , 5 1 5}$ & $\mathbf{5 0 , 8 7 1}$ & $\mathbf{1 4 0 , 4 8 0}$ & $\mathbf{1 7 9 , 5 8 6}$ \\
\hline Total LYs (months) & & & & &
\end{tabular}

Values in the table above are subject to rounding.

Table 8. Population LYs gained-new scenario.

\begin{tabular}{ccccccc}
\hline Treatment & $\mathbf{2 0 2 0}$ & $\mathbf{2 0 2 1}$ & $\mathbf{2 0 2 2}$ & $\mathbf{2 0 2 3}$ & $\begin{array}{c}\text { 3-Year } \\
\text { Combined }\end{array}$ & Life-Time \\
\hline Osimertinib & 2889 & 6938 & 11,074 & 13,036 & 31,048 & 46,325 \\
\hline Alectinib & 510 & 1224 & 1954 & 2700 & 5878 & 12,630 \\
\hline Crizotinib & 85 & 204 & 326 & 450 & 980 & 1842 \\
\hline Entrectinib & 85 & 204 & 326 & 450 & 980 & 2251 \\
\hline $\begin{array}{c}\text { Carboplatin }+ \\
\text { Pemetrexed }\end{array}$ & 3521 & 3355 & 3428 & 3502 & 10,285 & 10,285 \\
\hline $\begin{array}{c}\text { Carboplatin }+ \\
\text { Pemetrexed }+ \\
\text { Pembrolizumab }\end{array}$ & 9871 & 17,632 & 17,450 & 17,827 & 52,909 & 61,092 \\
\hline Pembrolizumab & 5922 & 11,566 & 14,372 & 14,480 & 40,418 & 52,138 \\
\hline Total LYs (months) & $\mathbf{2 2 , 8 8 3}$ & $\mathbf{4 1 , 1 2 4}$ & $\mathbf{4 8 , 9 2 8}$ & $\mathbf{5 2 , 4 4 5}$ & $\mathbf{1 4 2 , 4 9 8}$ & $\mathbf{1 8 6 , 5 6 2}$ \\
\hline Valn
\end{tabular}

Values in the table above are subject to rounding.

Table 9. Incremental population LYs gained.

\begin{tabular}{|c|c|c|c|c|c|c|}
\hline Scenario & $\begin{array}{c}\text { Base Year: } \\
2020\end{array}$ & 2021 & 2022 & 2023 & $\begin{array}{c}\text { 3-Year } \\
\text { Combined }\end{array}$ & $\begin{array}{l}\text { Lifetime } \\
\text { Combined }\end{array}$ \\
\hline Reference & 22,883 & 41,095 & 48,515 & 50,871 & 140,480 & 179,586 \\
\hline New & 22,883 & 41,124 & 48,928 & 52,445 & 142,498 & 186,562 \\
\hline $\begin{array}{l}\text { Incremental LYs } \\
\text { (months) }\end{array}$ & 0 & 29 & 414 & 1574 & 2018 & 6976 \\
\hline $\begin{array}{l}\text { Incremental LYs } \\
\text { (years) }\end{array}$ & 0 & 2 & 34 & 131 & 168 & 581 \\
\hline
\end{tabular}

Values in the table above are subject to rounding.

\subsection{Budget Impact}

For the base case, the impact to the Canadian publicly funded healthcare system resulted in an expenditure of $-\$ 1,415,057$ in year $1, \$ 7,028,238$ in year 2 , and $\$ 9,089,833$ in year 3, for a total 3-year impact of $\$ 14,703,014$ (Table 10). 
Table 10. Budget impact-base case and scenario analysis.

\begin{tabular}{|c|c|c|c|c|c|}
\hline & $\begin{array}{c}\text { Base Year: } \\
2020\end{array}$ & 2021 & 2022 & 2023 & $\begin{array}{c}\text { 3-Year } \\
\text { Combined }\end{array}$ \\
\hline $\begin{array}{c}\text { Molecular Testing } \\
\text { Cost }\end{array}$ & $\$ 0$ & $-\$ 3,787,555$ & $\$ 4,007,510$ & $\$ 5,881,902$ & $\$ 6,101,857$ \\
\hline Drug Cost & $\$ 0$ & $-\$ 1,646,575$ & $-\$ 1,668,394$ & $-\$ 1,701,711$ & $-\$ 5,016,680$ \\
\hline Administrative Cost & $\$ 0$ & $\$ 164,166$ & $\$ 750,755$ & $\$ 885,968$ & $\$ 1,800,888$ \\
\hline Supportive Cost & $\$ 0$ & $\$ 3,854,907$ & $\$ 3,938,368$ & $\$ 4,023,674$ & $\$ 11,816,949$ \\
\hline Base Case & $\$ 0$ & $-\$ 1,415,057$ & $\$ 7,028,238$ & $\$ 9,089,833$ & $\$ 14,703,014$ \\
\hline Scenario Analysis * & $\$ 0$ & $\$ 3,854,907$ & $\$ 3,938,368$ & $\$ 4,023,674$ & $\$ 11,816,949$ \\
\hline
\end{tabular}

\subsection{Sensitivity and Scenario Analysis}

\subsubsection{Sensitivity Analysis}

The one-way sensitivity analyses varied each assumption made in the development of the model by a specified amount. The net difference and percent change from base case of the most sensitive parameters is presented in Table 11. The estimated costs of testing were most sensitive to assumptions about broad-based NGS testing performed and the proportion of patients unable to continue due to tissue exhaustion. The full sensitivity analysis results are listed in Appendix B.

Table 11. One-way sensitivity analysis results.

\begin{tabular}{|c|c|c|c|c|c|c|}
\hline Parameter & $\begin{array}{c}\text { Base Year: } \\
2020\end{array}$ & 2021 & 2022 & 2023 & $\begin{array}{c}\text { 3-Year } \\
\text { Combined }\end{array}$ & $\%$ Change \\
\hline Base Case & $\$ 0$ & $-\$ 1,415,057$ & $\$ 7,028,238$ & $\$ 9,089,833$ & $\$ 14,703,014$ & \\
\hline \multicolumn{7}{|c|}{ Adequate tissue for testing $(84 \%)$} \\
\hline $74 \%(-10 \%)$ & $\$ 0$ & $-\$ 524,413$ & $\$ 8,409,393$ & $\$ 10,607,081$ & $\$ 18,492,061$ & $26 \%$ \\
\hline $94 \%(+10 \%)$ & $\$ 0$ & $-\$ 2,305,700$ & $\$ 5,647,084$ & $\$ 7,572,584$ & $\$ 10,913,968$ & $-26 \%$ \\
\hline \multicolumn{7}{|c|}{ Broad-based NGS testing performed ( $25 \%)$} \\
\hline $0 \%(-25 \%)$ & $\$ 0$ & $\$ 1,092,414$ & $\$ 11,703,143$ & $\$ 14,342,135$ & $\$ 27,137,692$ & $85 \%$ \\
\hline $50 \%(+25 \%)$ & $\$ 0$ & $-\$ 3,922,527$ & $\$ 2,353,334$ & $\$ 3,837,530$ & $\$ 2,268,337$ & $-85 \%$ \\
\hline $75 \%(+50 \%)$ & $\$ 0$ & $-\$ 6,429,997$ & $-\$ 2,321,571$ & $-\$ 1,414,773$ & $-\$ 10,166,341$ & $-169 \%$ \\
\hline $\begin{array}{c}100 \% \\
(+75 \%)\end{array}$ & $\$ 0$ & $-\$ 8,937,467$ & $-\$ 6,996,476$ & $-\$ 6,667,076$ & $-\$ 22,601,018$ & $-254 \%$ \\
\hline \multicolumn{7}{|c|}{ Patients unable to continue due to tissue exhaustion $(29 \%)$} \\
\hline $19 \%(-10 \%)$ & $\$ 0$ & $-\$ 3,970,100$ & $\$ 2,231,863$ & $\$ 3,697,009$ & $\$ 1,958,771$ & $-87 \%$ \\
\hline $39 \%(+10 \%)$ & $\$ 0$ & $\$ 1,139,987$ & $\$ 11,824,614$ & $\$ 14,482,656$ & $\$ 27,447,258$ & $87 \%$ \\
\hline
\end{tabular}

\subsubsection{Scenario Analysis}

The net expenditure for the scenario analysis from a Canadian testing budget perspective was $\$ 3,854,907$ in year $1, \$ 3,938,368$ in year 2 , and $\$ 4,023,674$ in year 3, for a total 3-year impact of $\$ 11,816,949$ (Table 10).

\section{Discussion}

The reliance on tissue-based biomarker testing in lung cancer presents a barrier to accessing timely and optimal care for the tissue-limited patient population. Using aNSCLC as an example, this study presents a case to assess the health and budget implications of adopting LBx-based CGP testing in tissue-limited patients (insufficient tissue/exhausted tissue and who require re-biopsies) from a Canadian healthcare perspective (TL-LBx-CGP).

Our findings suggest widespread public funding of TL-LBx-CGP could allow as many as 346 more aNSCLC patients to obtain targeted therapies as opposed to chemotherapies, immunotherapies, and chemo-immunotherapies (Figure 6). Consequently, an increased number of patients on targeted therapies translates to improved health outcomes, with the first 3 years of funding TL-LBx-CGP leading to an incremental gain of 168 LYs within 
Canadian publicly-funded healthcare systems. An additional $574 \mathrm{LYs}$ are gained beyond the 3-year time horizon (Tables 8 and 9); however, associated downstream costs were not estimated for this time period. The incremental gain in the new scenario versus the reference can be attributed directly to the increase in the number of patients receiving targeted therapy as opposed to systemic therapies.

The incremental gain from the health impact was associated with an overall budget impact of approximately $\$ 14.7 \mathrm{M}$ in the first 3 years of implementation (Table 10). This includes a reduction in costs in year 1 with both drug $(-\$ 3.8 \mathrm{M})$ and administrative costs $(-\$ 1.6 \mathrm{M})$. Cost reduction in year 1 is primarily driven by reducing the use of triplet chemo-immunotherapy (Carboplatin+Pemetrexed+Pembrolizumab), which is more costly compared to tyrosine kinase inhibitors (TKIs) therapy (Table 6). In the reference scenario, an increased number of tissue-limited patients were allocated to the triplet chemoimmunotherapy due to the lack of an appropriate biomarker test.

Moving from year 1 to year 2, cost reduction is no longer observed as improved health outcomes associated with TKIs (in the new scenario) allow patients to remain on treatment longer without progression, increasing drug costs. Improved health outcomes through improved access to TKIs also translates to carry-over patients that further increase healthcare expenditure. Despite this, some cost offsets due to lowered administrative costs are achieved, as an increased number of patients on oral TKIs reduces the demand for chemotherapies, immunotherapies, and chemo-immunotherapies requiring intravenous administration. Lower administrative costs are persistent throughout the time horizon, as the number of patients on targeted therapies increases from year to year.

A strength of this study is the holistic perspective applied, which not only highlights the testing journey of a patient, but also how testing influences treatment decisions, leading to the accumulation of appropriate costs and health outcomes. Despite recognizing the need to consider a wider impact to the health system, we are aware some Canadian budget holders may want to more narrowly focus on impact to the laboratory budget alone. As such, we also examined the impact of funding TL-LBx-CGP from the Canadian testing budget perspective in a scenario analysis. From this perspective, only molecular genetic testing costs were considered, resulting in a total 3-year impact of $\$ 11 \mathrm{M}$.

Despite the need to consider a system-wide impact, previous studies have tended to focus on studying testing or targeted therapies in a silo. A similar study by Johnston et al. focused on the economic and health impact of adopting NGS and TL-LBx-CGP in NSCLC, which resulted in a lower 3-year budget $(\sim 4.5 \mathrm{M})$ than this study [37]. The Johnston et al. study focused mainly on tissue-biopsy, and made a simplifying assumption that $5 \%$ of patients had unavailable tissue for testing. This study adds a more detailed and disaggregated breakdown of tissue-limited aNSCLC patients. Additionally, this study includes all potential drug treatment costs.

A potential limitation of our analysis is that it relies heavily on epidemiological, molecular genetic testing and cost inputs. As such, assumptions made in the development of the model were tested through a series of one-way sensitivity analyses (Table 11). Notably, tissue exhaustion rates were one of the most influential parameters, in which a variance of $10 \%$ caused an $88 \%$ from the reference case. The lack of an accurate estimate is a limitation of our findings, as it necessarily added simplifying assumptions regarding best-practices surrounding tissue conservation during molecular genetic testing procedures. In practice, the average percentage of exhausted tissue may be lower, as laboratory professionals are motivated to preserve as much of a tissue sample as possible.

Further, results in the model are distinctly sensitive to the adoption rates of NGS vs. single-gene testing, and an increase in NGS adoption (versus single-gene testing) presents a case for substantial cost-savings. Nonetheless, heterogeneity of testing adoption rates, treatment patterns, and unit costs across Canada can greatly impact the overall results. Also, this study did not evaluate the pharmacoeconomic impact of clinical trial options, which generally contribute to improved health outcomes (versus real-world practice), and are backed using funds outside the healthcare budget [38]. Future analysts should also consider 
that technology is likely to be more productively efficient over time as more therapies are authorized and reimbursed, as well as the inclusion of productivity measures to capture the societal impact associated with the adoption of this technology for TL-LBx-CGP.

\section{Conclusions}

In summary, this study sought to characterize the health and budget impact of publicly funding LBx-CGP in tissue-limited aNSCLC patients from a Canadian healthcare perspective. The modelling resulted in 346 more patients accessing targeted therapies, adding 168 population LYs in the first 3 years of implementation (with the opportunity to gain 574 LYs beyond the time horizon). The added health impact was attributed to a modest budget impact of $\$ 14.7 \mathrm{M}$ over 3 years.

Supplementary Materials: The following are available online at https://www.mdpi.com/article/ 10.3390/curroncol28060441/s1, Table S1: Drug Cost for 1-Year (without carry-over), Table S2: IV Drug Unit Costs, Table S3: Patient Characteristics, Table S4: Number of Cycles Calculations for IV Therapies, Table S5: Chemotherapy Treatment, Table S6: Chemo-immunotherapy Treatment, Table S7: Immunotherapy Treatment, Table S8: Immunotherapy Treatment, Table S9: Administrative Costs for Oral and IV treatments, Table S10: Supportive Costs for Oral and IV treatments.

Author Contributions: Conceptualization, Y.P.P. and J.N.; Methodology, Y.P.P., D.H. and J.N.; Software, Y.P.P.; Validation, Y.P.P., J.N. and D.H.; Formal Analysis, Y.P.P.; Investigation, Y.P.P. and J.N.; Data Curation, Y.P.P.; Writing — Original Draft Preparation, Y.P.P.; Writing-Review \& Editing, Y.P.P., D.H., J.N., N.B.L. and B.M.; Supervision, J.N.; Project Administration, Y.P.P. All authors have read and agreed to the published version of the manuscript.

Funding: This research received no external funding.

Institutional Review Board Statement: Not applicable.

Informed Consent Statement: Not applicable.

Data Availability Statement: Medical cost data was obtained from the Ontario Case Costing Initiative. Clinical trial information was obtained from clinicaltrials.gov.

Conflicts of Interest: The FoundationOne CDx and FoundationOne liquid test are products of Hoffmann-La Roche Limited, and costs and other data regarding these tests cited in this research was proved by the company. Yuti Patel and Julian Nam are employees of Hoffmann-La Roche Ltd. Donald Husereau of the University of Ottawa, Natasha Leighl of Princess Margaret Cancer Care Center, and Barbara Melosky of British Columbia Cancer Care Agency received fees as consultants in the conduct of this study.

\section{Appendix A}

Table A1. Annual cost per patient per therapy.

\begin{tabular}{|c|c|c|c|c|c|}
\hline Line of Therapy & Treatment & Drug Cost per Year & $\begin{array}{c}\text { Administrative Cost } \\
\text { per Year }\end{array}$ & $\begin{array}{c}\text { Supportive Cost per } \\
\text { Year }\end{array}$ & $\begin{array}{l}\text { Cost Per Patient Per } \\
\text { Therapy per Year }\end{array}$ \\
\hline \multirow{7}{*}{$1 \mathrm{~L}$} & Osimertinib * & $\$ 107,558.20$ & $\$ 194.33$ & $\$ 8192.96$ & $\$ 115,945.50$ \\
\hline & Alectinib* & $\$ 123,224.00$ & $\$ 194.33$ & $\$ 8192.96$ & $\$ 131,611.30$ \\
\hline & Crizotinib* & $\$ 94,900.00$ & $\$ 194.33$ & $\$ 8192.96$ & $\$ 103,287.30$ \\
\hline & Entrectinib * & $\$ 104,386.35$ & $\$ 194.33$ & $\$ 8192.96$ & $\$ 112,773.65$ \\
\hline & $\begin{array}{l}\text { Carboplatin + } \\
\text { Pemetrexed }\end{array}$ & $\$ 10,157.00$ & $\$ 5293.63$ & $\$ 2413.76$ & $\$ 17,864.38$ \\
\hline & $\begin{array}{c}\text { Pembrolizumab + } \\
\text { Carboplatin }+ \\
\text { Pemetrexed }\end{array}$ & $\$ 133,307.14$ & $\$ 9722.99$ & $\$ 4433.43$ & $\$ 147,463.56$ \\
\hline & Pembrolizumab & $\$ 131,212.19$ & $\$ 11,127.42$ & $\$ 5073.82$ & $\$ 147,413.43$ \\
\hline
\end{tabular}


Table A1. Cont.

\begin{tabular}{|c|c|c|c|c|c|}
\hline Line of Therapy & Treatment & Drug Cost per Year & $\begin{array}{c}\text { Administrative Cost } \\
\text { per Year }\end{array}$ & $\begin{array}{c}\text { Supportive Cost per } \\
\text { Year }\end{array}$ & $\begin{array}{l}\text { Cost Per Patient Per } \\
\text { Therapy per Year }\end{array}$ \\
\hline \multirow{5}{*}{$2 \mathrm{~L}$} & $\begin{array}{l}\text { Carboplatin+ } \\
\text { Pemetrexed }\end{array}$ & $\$ 10,157.00$ & $\$ 5293.63$ & $\$ 2413.76$ & $\$ 17,864.38$ \\
\hline & Docetaxel & $\$ 4417.90$ & $\$ 2160.66$ & $\$ 985.21$ & $\$ 7563.77$ \\
\hline & Nivolumab & $\$ 19,982.41$ & $\$ 2484.76$ & $\$ 1132.99$ & $\$ 23,600.17$ \\
\hline & Pembrolizumab & $\$ 48,408.38$ & $\$ 4105.26$ & $\$ 1871.89$ & $\$ 54,385.54$ \\
\hline & Atezolizumab & $\$ 27,465.39$ & $\$ 3024.93$ & $\$ 1379.29$ & $\$ 31,869.61$ \\
\hline
\end{tabular}

* These treatments are associated with carry-over as treatment duration spans over a year; 1L: first-line, 2L: second-line.

\section{Appendix B}

Table A2. One-way sensitivity analysis results.

\begin{tabular}{|c|c|c|c|c|c|c|}
\hline Parameter & Base Year: 2020 & 2021 & 2022 & 2023 & 3-Year Combined & $\%$ Change \\
\hline Base Case & $\$ 0$ & $-\$ 1,415,057$ & $\$ 7,028,238$ & $\$ 9,089,833$ & $\$ 14,703,014$ & \\
\hline \multicolumn{7}{|c|}{ Lung cancer patients with NSCLC (85\%) } \\
\hline $75 \%(-10 \%)$ & $\$ 0$ & $-\$ 1,248,579$ & $\$ 6,201,387$ & $\$ 8,020,440$ & $\$ 12,973,248$ & $-12 \%$ \\
\hline $95 \%(+10)$ & $\$ 0$ & $-\$ 1,581,534$ & $\$ 7,855,090$ & $\$ 10,159,225$ & $\$ 16,432,781$ & $12 \%$ \\
\hline \multicolumn{7}{|c|}{ NSCLC patients with advanced disease (Stage 3B/4A) $(63 \%)$} \\
\hline $53 \%(+10 \%)$ & $\$ 0$ & $-\$ 1,190,444$ & $\$ 5,912,645$ & $\$ 7,647,002$ & $\$ 12,369,203$ & $-16 \%$ \\
\hline $73 \%(-10 \%)$ & $\$ 0$ & $-\$ 1,639,669$ & $\$ 8,143,832$ & $\$ 10,532,663$ & $\$ 17,036,826$ & $16 \%$ \\
\hline \multicolumn{7}{|c|}{ Patients with non-squamous NSCLC (70\%) } \\
\hline $60 \%(-10 \%)$ & $\$ 0$ & $-\$ 1,212,906$ & $\$ 6,024,204$ & $\$ 7,791,285$ & $\$ 12,602,584$ & $-14 \%$ \\
\hline $80 \%(+10 \%)$ & $\$ 0$ & $-\$ 1,617,207$ & $\$ 8,032,272$ & $\$ 10,388,380$ & $\$ 16,803,445$ & $14 \%$ \\
\hline \multicolumn{7}{|c|}{ Patients who receive treatment $(30 \%)$} \\
\hline $20 \%(-10 \%)$ & $\$ 0$ & $-\$ 943,371$ & $\$ 4,685,492$ & $\$ 6,059,888$ & $\$ 9,802,010$ & $-33 \%$ \\
\hline $40 \%(+10 \%)$ & $\$ 0$ & $-\$ 1,886,742$ & $\$ 9,370,985$ & $\$ 12,119,777$ & $\$ 19,604,019$ & $33 \%$ \\
\hline \multicolumn{7}{|c|}{ Biomarker not tested, excluding PD-L1 (28\%) } \\
\hline $18 \%(-10 \%)$ & $\$ 0$ & $-\$ 2,080,995$ & $\$ 6,943,984$ & $\$ 9,138,068$ & $\$ 14,001,057$ & $-5 \%$ \\
\hline $38 \%(+10 \%)$ & $\$ 0$ & $-\$ 749,118$ & $\$ 7,112,493$ & $\$ 9,041,597$ & $\$ 15,404,972$ & $5 \%$ \\
\hline \multicolumn{7}{|c|}{ Patients with insufficient tissue for biomarker testing $(10 \%)$} \\
\hline $5 \%(-5 \%)$ & $\$ 0$ & $-\$ 1,888,215$ & $\$ 5,959,356$ & $\$ 7,865,877$ & $\$ 11,937,019$ & $-19 \%$ \\
\hline $15 \%(+5 \%)$ & $\$ 0$ & $-\$ 941,898$ & $\$ 8,097,120$ & $\$ 10,313,788$ & $\$ 17,469,010$ & $19 \%$ \\
\hline \multicolumn{7}{|c|}{ Adequate tissue for testing $(84 \%)$} \\
\hline $74 \%(-10 \%)$ & $\$ 0$ & $-\$ 524,413$ & $\$ 8,409,393$ & $\$ 10,607,081$ & $\$ 18,492,061$ & $26 \%$ \\
\hline $94 \%(+10 \%)$ & $\$ 0$ & $-\$ 2,305,700$ & $\$ 5,647,084$ & $\$ 7,572,584$ & $\$ 10,913,968$ & $-26 \%$ \\
\hline \multicolumn{7}{|c|}{ Repeat biopsy performed $(80 \%)$} \\
\hline $70 \%(-10 \%)$ & $\$ 0$ & $-\$ 1,030,780$ & $\$ 7,797,816$ & $\$ 9,961,022$ & $\$ 16,728,058$ & $14 \%$ \\
\hline $90 \%(+10 \%)$ & $\$ 0$ & $-\$ 1,799,333$ & $\$ 6,258,660$ & $\$ 8,218,643$ & $\$ 12,677,971$ & $-14 \%$ \\
\hline \multicolumn{7}{|c|}{ Broad-based NGS testing performed ( $25 \%)$} \\
\hline $0 \%(-25 \%)$ & $\$ 0$ & $\$ 1,092,414$ & $\$ 11,703,143$ & $\$ 14,342,135$ & $\$ 27,137,692$ & $85 \%$ \\
\hline $50 \%(+25 \%)$ & $\$ 0$ & $-\$ 3,922,527$ & $\$ 2,353,334$ & $\$ 3,837,530$ & $\$ 2,268,337$ & $-85 \%$ \\
\hline $75 \%(+50 \%)$ & $\$ 0$ & $-\$ 6,429,997$ & $-\$ 2,321,571$ & $-\$ 1,414,773$ & $-\$ 10,166,341$ & $-169 \%$ \\
\hline $100 \%(+75 \%)$ & $\$ 0$ & $-\$ 8,937,467$ & $-\$ 6,996,476$ & $-\$ 6,667,076$ & $-\$ 22,601,018$ & $-254 \%$ \\
\hline \multicolumn{7}{|c|}{ Patients unable to continue due to tissue exhaustion $(29 \%)$} \\
\hline $19 \%(-10 \%)$ & $\$ 0$ & $-\$ 3,970,100$ & $\$ 2,231,863$ & $\$ 3,697,009$ & $\$ 1,958,771$ & $-87 \%$ \\
\hline $39 \%(+10 \%)$ & $\$ 0$ & $\$ 1,139,987$ & $\$ 11,824,614$ & $\$ 14,482,656$ & $\$ 27,447,258$ & $87 \%$ \\
\hline \multicolumn{7}{|c|}{ LBx-CGP (FoundationOne Liquid CDx ${ }^{\circledR}$ ) discount } \\
\hline Discount $(25 \%)$ & $\$ 0$ & $-\$ 2,543,748$ & $\$ 5,875,110$ & $\$ 7,911,727$ & $\$ 11,243,088$ & $-24 \%$ \\
\hline Discount (50\%) & $\$ 0$ & $-\$ 3,672,440$ & $\$ 4,721,981$ & $\$ 6,733,621$ & $\$ 7,783,162$ & $-47 \%$ \\
\hline Discount $(75 \%)$ & $\$ 0$ & $-\$ 4,801,132$ & $\$ 3,568,853$ & $\$ 5,555,515$ & $\$ 4,323,236$ & $-71 \%$ \\
\hline
\end{tabular}


Table A2. Cont.

\begin{tabular}{|c|c|c|c|c|c|c|}
\hline Parameter & Base Year: 2020 & 2021 & 2022 & 2023 & 3-Year Combined & $\%$ Change \\
\hline Base Case & $\$ 0$ & $-\$ 1,415,057$ & $\$ 7,028,238$ & $\$ 9,089,833$ & $\$ 14,703,014$ & \\
\hline \multicolumn{7}{|c|}{ Single-gene testing discount } \\
\hline Discount (25\%) & $\$ 0$ & $-\$ 1,372,610$ & $\$ 7,071,604$ & $\$ 9,134,138$ & $\$ 14,833,132$ & $0.9 \%$ \\
\hline Discount (50\%) & $\$ 0$ & $-\$ 1,330,163$ & $\$ 7,114,970$ & $\$ 9,178,443$ & $\$ 14,963,249$ & $1.8 \%$ \\
\hline Discount $(75 \%)$ & $\$ 0$ & $-\$ 1,287,716$ & $\$ 7,158,335$ & $\$ 9,222,747$ & $\$ 15,093,366$ & $2.7 \%$ \\
\hline \multicolumn{7}{|c|}{ Re-biopsy discount } \\
\hline Discount (25\%) & $\$ 0$ & $-\$ 1,321,865$ & $\$ 7,123,448$ & $\$ 9,187,104$ & $\$ 14,988,687$ & $1.9 \%$ \\
\hline Discount (50\%) & $\$ 0$ & $-\$ 1,228,673$ & $\$ 7,218,657$ & $\$ 9,284,376$ & $\$ 15,274,360$ & $3.9 \%$ \\
\hline Discount $(75 \%)$ & $\$ 0$ & $-\$ 1,135,481$ & $\$ 7,313,867$ & $\$ 9,381,648$ & $\$ 15,560,033$ & $5.8 \%$ \\
\hline \multicolumn{7}{|c|}{ Broad-based NGS } \\
\hline Discount $(25 \%)$ & $\$ 0$ & $-\$ 1,385,730$ & $\$ 7,058,200$ & $\$ 9,120,443$ & $\$ 14,792,913$ & $0.6 \%$ \\
\hline Discount (50\%) & $\$ 0$ & $-\$ 1,356,403$ & $\$ 7,088,161$ & $\$ 9,151,054$ & $\$ 14,882,812$ & $1.2 \%$ \\
\hline Discount (75\%) & $\$ 0$ & $-\$ 1,327,077$ & $\$ 7,118,123$ & $\$ 9,181,664$ & $\$ 14,972,710$ & $1.8 \%$ \\
\hline
\end{tabular}

\section{References}

1. Slomka, A.; Mocan, T.; Wang, B.; Nenu, I.; Urban, S.K.; Gonzales-Carmona, M.; Schmidt-Wolf, I.G.H.; Lukacs-Kornek, V.; Strassburg, C.P.; Sparchez, Z.; et al. EVs as Potential New Therapeutic Tool/Target in Gastrointestinal Cancer and HCC. Cancers 2020, 12, 3019. [CrossRef]

2. Barlesi, F.; Mazieres, J.; Merlio, J.P.; Debieuvre, D.; Mosser, J.; Lena, H.; Ouafik, L.; Besse, B.; Rouquette, I.; Westeel, V.; et al. Routine molecular profiling of patients with advanced non-small-cell lung cancer: Results of a 1-year nationwide programme of the French Cooperative Thoracic Intergroup (IFCT). Lancet 2016, 387, 1415-1426. [CrossRef]

3. Jardim, D.L.; Schwaederle, M.; Wei, C.; Lee, J.J.; Hong, D.S.; Eggermont, A.M.; Schilsky, R.L.; Mendelsohn, J.; Lazar, V.; Kurzrock, R. Impact of a Biomarker-Based Strategy on Oncology Drug Development: A Meta-analysis of Clinical Trials Leading to FDA Approval. J. Natl. Cancer Inst. 2015, 107, djv253. [CrossRef] [PubMed]

4. Khoury, J.D.; Catenacci, D.V. Next-generation companion diagnostics: Promises, challenges, and solutions. Arch. Pathol. Lab. Med. 2015, 139, 11-13. [CrossRef]

5. Ali, S.M.; Hensing, T.; Schrock, A.B.; Allen, J.; Sanford, E.; Gowen, K.; Kulkarni, A.; He, J.; Suh, J.H.; Lipson, D.; et al. Comprehensive Genomic Profiling Identifies a Subset of Crizotinib-Responsive ALK-Rearranged Non-Small Cell Lung Cancer Not Detected by Fluorescence In Situ Hybridization. Oncologist 2016, 21, 762-770. [CrossRef]

6. Frampton, G.M.; Fichtenholtz, A.; Otto, G.A.; Wang, K.; Downing, S.R.; He, J.; Schnall-Levin, M.; White, J.; Sanford, E.M.; An, P.; et al. Development and validation of a clinical cancer genomic profiling test based on massively parallel DNA sequencing. Nat. Biotechnol. 2013, 31, 1023-1031. [CrossRef]

7. Suh, J.H.; Johnson, A.; Albacker, L.; Wang, K.; Chmielecki, J.; Frampton, G.; Gay, L.; Elvin, J.A.; Vergilio, J.A.; Ali, S.; et al. Comprehensive Genomic Profiling Facilitates Implementation of the National Comprehensive Cancer Network Guidelines for Lung Cancer Biomarker Testing and Identifies Patients Who May Benefit From Enrollment in Mechanism-Driven Clinical Trials. Oncologist 2016, 21, 684-691. [CrossRef]

8. Melosky, B.; Cheema, P.; Agulnik, J.; Albadine, R.; Bebb, D.G.; Blais, N.; Burkes, R.; Butts, C.; Card, P.B.; Chan, A.M.Y.; et al. Canadian perspectives: Update on inhibition of ALK-positive tumours in advanced non-small-cell lung cancer. Curr. Oncol. 2018, 25, 317-328. [CrossRef] [PubMed]

9. Melosky, B.; Banerji, S.; Blais, N.; Chu, Q.; Juergens, R.; Leighl, N.B.; Liu, G.; Cheema, P. Canadian consensus: A new systemic treatment algorithm for advanced EGFR-mutated non-small-cell lung cancer. Curr. Oncol. 2020, 27, e146-e155. [CrossRef] [PubMed]

10. Stockley, T.; Souza, C.A.; Cheema, P.K.; Melosky, B.; Kamel-Reid, S.; Tsao, M.S.; Spatz, A.; Karsan, A. Evidence-based best practices for EGFR T790M testing in lung cancer in Canada. Curr. Oncol. 2018, 25, 163-169. [CrossRef] [PubMed]

11. Bebb, D.G.; Banerji, S.; Blais, N.; Desmeules, P.; Gill, S.; Grin, A.; Feilotter, H.; Hansen, A.R.; Hyrcza, M.; Krzyzanowska, M.; et al. Canadian Consensus for Biomarker Testing and Treatment of TRK Fusion Cancer in Adults. Curr. Oncol. 2021, 28, 523-548. [CrossRef] [PubMed]

12. Johnston, K.M.; Sheffield, B.S.; Yip, S.; Lakzadeh, P.; Qian, C.; Nam, J. Costs of in-house genomic profiling and implications for economic evaluation: A case example of non-small cell lung cancer (NSCLC). J. Med. Econ. 2020, 23, 1123-1129. [CrossRef] [PubMed]

13. Yip, S.; Christofides, A.; Banerji, S.; Downes, M.R.; Izevbaye, I.; Lo, B.; MacMillan, A.; McCuaig, J.; Stockley, T.; Yousef, G.M.; et al. A Canadian guideline on the use of next-generation sequencing in oncology. Curr. Oncol. 2019, 26, e241-e254. [CrossRef]

14. Gaman, M.A.; Cozma, M.A.; Dobrica, E.C.; Cretoiu, S.M.; Gaman, A.M.; Diaconu, C.C. Liquid Biopsy and Potential Liquid Biopsy-Based Biomarkers in Philadelphia-Negative Classical Myeloproliferative Neoplasms: A Systematic Review. Life 2021, 11, 677. [CrossRef] 
15. Reckamp, K.L. Molecular Targets Beyond the Big 3. Thorac. Surg. Clin. 2020, 30, 157-164. [CrossRef] [PubMed]

16. Lim, C.; Tsao, M.S.; Le, L.W.; Shepherd, F.A.; Feld, R.; Burkes, R.L.; Liu, G.; Kamel-Reid, S.; Hwang, D.; Tanguay, J.; et al. Biomarker testing and time to treatment decision in patients with advanced nonsmall-cell lung cancer. Ann. Oncol. 2015, 26, 1415-1421. [CrossRef]

17. Gierman, H.J.; Goldfarb, S.; Labrador, M.; Weipert, C.M.; Getty, B.; Skrzypczak, S.M.; Catasus, C.; Carbral, S.; Singaraju, M.; Singleton, N.; et al. Genomic testing and treatment landscape in patients with advanced non-small cell lung cancer (aNSCLC) using real-world data from community oncology practices. J. Clin. Oncol. 2019, 37, 1585. [CrossRef]

18. Middleton, G.; Fletcher, P.; Popat, S.; Savage, J.; Summers, Y.; Greystoke, A.; Gilligan, D.; Cave, J.; O’Rourke, N.; Brewster, A.; et al. Publisher Correction: The National Lung Matrix Trial of personalized therapy in lung cancer. Nature 2020, 585, E21. [CrossRef]

19. FDA. Summary of Safety and Effectiveness Data (SSED). FDA Premarket Approval (PMA). Available online: https://www. accessdata.fda.gov/scripts/cdrh/cfdocs/cfpma/pma.cfm?id=p190032 (accessed on 24 February 2021).

20. FDA. FoundationOne Liquid CDx-P190032. Available online: https://www.fda.gov/medical-devices/recently-approveddevices / foundationone-liquid-cdx-p190032\#: \{\}:text=The\%20FoundationOne\%20Liquid\%20CDx\%20is, who\%20may\%20 benefit\%20from\%20treatment (accessed on 24 February 2021).

21. Ramalingam, S.S.; Vansteenkiste, J.; Planchard, D.; Cho, B.C.; Gray, J.E.; Ohe, Y.; Zhou, C.; Reungwetwattana, T.; Cheng, Y.; Chewaskulyong, B.; et al. Overall Survival with Osimertinib in Untreated, EGFR-Mutated Advanced NSCLC. N. Engl. J. Med. 2020, 382, 41-50. [CrossRef]

22. CADTH. Pan-Canadian Oncology Drug Review Final Clinical Guidance Report. Available online: https://www.cadth.ca/sites/ default/files/pcodr/pcodr_alectinib_alecensaro_nsclc_1stln_fn_cgr.pdf (accessed on 24 February 2021).

23. Shaw, A.T.; Riely, G.J.; Bang, Y.J.; Kim, D.W.; Camidge, D.R.; Solomon, B.J.; Varella-Garcia, M.; Iafrate, A.J.; Shapiro, G.I.; Usari, T.; et al. Crizotinib in ROS1-rearranged advanced non-small-cell lung cancer (NSCLC): Updated results, including overall survival, from PROFILE 1001. Ann. Oncol. 2019, 30, 1121-1126. [CrossRef] [PubMed]

24. Dziadziuszko, R.; Krebs, M.G.; De Braud, F.; Siena, S.; Drilon, A.; Doebele, R.C.; Patel, M.R.; Cho, B.C.; Liu, S.V.; Ahn, M.J.; et al. Updated Integrated Analysis of the Efficacy and Safety of Entrectinib in Locally Advanced or Metastatic ROS1 Fusion-Positive Non-Small-Cell Lung Cancer. J. Clin. Oncol. 2021, 39, 1253-1263. [CrossRef] [PubMed]

25. NIH. Study of Pemetrexed+Platinum Chemotherapy with or without Pembrolizumab (MK-3475) in Participants with First Line Metastatic Nonsquamous Non-Small Cell Lung Cancer (MK-3475-189/KEYNOTE-189). Available online: https:/ / clinicaltrials. gov/ct2/show / NCT03950674 (accessed on 24 February 2021).

26. NIH. Merck Sharp \& Dohme Corp. Study of Pembrolizumab (MK-3475) Compared to Platinum-Based Chemotherapies in Participants with Metastatic Non-Small Cell Lung Cancer (MK-3475-024/KEYNOTE-024). Available online: https:/ / clinicaltrials. gov/ct2/show / NCT02142738 (accessed on 24 February 2021).

27. Calpe-Armero, P.; Ferriols-Lisart, R.; Ferriols-Lisart, F.; Perez-Pitarch, A. Effectiveness of Nivolumab versus Docetaxel as Second-Line Treatment in Non-Small Cell Lung Cancer Patients in Clinical Practice. Chemotherapy 2017, 62, 374-380. [CrossRef] [PubMed]

28. NIH. Squibb B-M. Study of BMS-936558 (Nivolumab) Compared to Docetaxel in Previously Treated Metastatic Non-Squamous NSCLC (CheckMate057). Available online: https:/ / clinicaltrials.gov/ct2/show /NCT01673867 (accessed on 24 February 2021).

29. NIH. Merck Sharp \& Dohme Corp. Study of Two Doses of Pembrolizumab (MK-3475) Versus Docetaxel in Previously Treated Participants with Non-Small Cell Lung Cancer (MK-3475-010/KEYNOTE-010). Available online: https:/ / clinicaltrials.gov / ct2 / show / NCT01905657 (accessed on 24 February 2021).

30. NIH. A Study of Atezolizumab Compared with Docetaxel in Participants with Locally Advanced or Metastatic Non-Small Cell Lung Cancer Who Have Failed Platinum-Containing Therapy (OAK). Available online: https://clinicaltrials.gov/ct2/show / NCT02008227 (accessed on 24 February 2021).

31. Ministry of Health and Long Term Care. Ontario Case Costing Initiative. Available online: https://hsim.health.gov.on.ca/ hdbportal/?destination=front_page (accessed on 24 February 2021).

32. Cancer Care Ontario (Web Page) Regimen Monographs. Available online: https://www.cancercareontario.ca/en/drugformulary/ regimens (accessed on 24 February 2021).

33. Tam, V.C.; Ko, Y.J.; Mittmann, N.; Cheung, M.C.; Kumar, K.; Hassan, S.; Chan, K.K. Cost-effectiveness of systemic therapies for metastatic pancreatic cancer. Curr. Oncol. 2013, 20, e90-e106. [CrossRef]

34. Ontario Ministry of Health and Long Term Care (Web Page) Ontario Drug Benefit Program: Dispensing Fees. Available online: https://www.health.gov.on.ca/en/public/programs/drugs/programs/odb/opdp_dispensing_fees.aspx (accessed on 24 February 2021).

35. Ontario Ministry of Health and Long Term Care. Schedule of Benefits for Physician Services. 2016. Available online: https: //www.health.gov.on.ca/en/pro/programs/ohip/sob/physserv/sob_master.pdf (accessed on 24 February 2021).

36. Ontario Ministry of Health and Long Term Care. Schedule of Benefits for Laboratory Services. 2013. Available online: https: //www.health.gov.on.ca/en/pro/programs/ohip/sob/lab/lab_mn2020.pdf (accessed on 24 February 2021).

37. Johnston, K.M.; Sheffield, B.S.; Yip, S.; Lakzadeh, P.; Qian, C.; Nam, J. Comprehensive genomic profiling for non-small-cell lung cancer: Health and budget impact. Curr. Oncol. 2020, 27, e569-e577. [CrossRef] [PubMed]

38. Tran, D.T.; Akpinar, I.; Jacobs, P. The Costs of Industry-Sponsored Drug Trials in Canada. Pharm. Open 2020, 4, 353-359. [CrossRef] 